\title{
PERAN TOKOH PEMUDA DALAM MENINGKATKAN PARTISIPASI KARANG TARUNA DI DESA NANJUNG MARGAASIH
}

\author{
1Tiana Nirmalasari, ${ }^{2}$ Novi Widiastuti \\ 1,2IKIP Siliwangi \\ 1 tiananirmalasari123@gmail.com, ${ }^{2}$ noviw9@gmail.com
}

\begin{abstract}
Abstrak
Pemuda harus dilatih dan dibina agar memiliki jiwa sosial yang tinggi, memiliki nilai dan moral yang baik dan meningkatnya idealisme. Begitupun dalam tujuan penelitian ini adalah untuk menjabarkan (1) upaya tokoh pemuda dalam meningkatkan partisipasi karang taruna di desa nanjung margaasih (2) Bagaimana partisipasi anggota karang taruna dalamkegiatan-kegiatan karang taruna. Dalam penelitian ini Teori yang digunakan adalah teori kepemudaan, teori kepemimpinan dan teori partisipasi. Dalam penelitian ini, peneliti menggunakan metode deskriptif kualitatif dengan teknik pengumpulan data melalui wawancara dan observasi. Penelitian ini dilakukan di RW 03 di Desa Nanjung Kecamatan Margaasih Kabupaten Bandung, yang menjadi responden penelitian adalah ketua, sekretaris, bendahara dan tiga anggota. Hasil dari penelitian ini yaitu (1) peran tokoh pemuda adalah membina, membimbing, dan memberikan inovasi (2) bentuk partisipasi ada partisipasi menggunakan harta, partisipasi menggunakan tenaga, partisipasi menggunakan uang, partisipasi menggunakan fikiran dan partisipasi menggunakan keterampilan.
\end{abstract}

Kata Kunci: Karang Taruna, Partisipasi, Tokoh Pemuda.

\section{PENDAHULUAN}

Pemuda adalah salah satu mesin penggerak sebuah bangsa. Mereka merupakan energi dinamis yang menggulirkan sejarah dan memimpin kebaharuan baik dalam bidang politik, ekonomi, sosial hingga budaya. Khusus di Indonesia, sejarah kemerdekaan akan sulit dibayangkan tanpa kiprah para pemuda. Karena perannya tersebut, berbagai kajian tentang kepemudaan sangatlah penting untuk dilakukan baik pada skala nasional ataupun internasional. Di Indonesia sendiri, pemerintah memberikan perhatian khusus melalui Kementrian Pemuda dan Olah Raga. Sedangkan pada tataran internasional perhatian terhadap kepemudaan direalisasikan melalui berbagai proyek, baik di bawah PBB (UN Youth dan UNDP Youth Strategy) atau dalam bentuk Organisasi Nonkepemerintahan seperti International Youth Rights atau World Assembly of Youth (WAY).

Pemuda harus memiliki jiwa sosial yang tinggi Karena hal tersebut adalah modal utama untuk terjun di kalangan masyarakat. Namun dengan berkembangnya zaman kini pemuda semakin acuh dengan sekitarnya. Pemuda memiliki karakteristik yang tidak mau di atur, selalu ingin mecoba hal yang baru. Mernurut UU No. 40/2009 tentang Kepemudaan, pemuda atau pemuda didefinisikan sebagai "warga negara yang memasuki usia 15 tahun-30 tahun dimana usia tersebut merupakan usia yang mengalami perkembangan dan pertumbuhan“. Pada tahun 2015, berdasarkan data 
Badan Pusat Statistik (BPS) jumlah pemuda indonesia mencapai 62,4 juta orang atau sama dengan 25 persen dari seluruh penduduk di Indonesia.

Karakter pemuda sangatlah bervariasi salah satunya pertentangan dalam dirinya dan pertentangan dengan orang sekelilingnya. Hal tersebut menimbulkan beberapa permasalahan diantaranya penurunanya idealisme, menurunnya rasa nasionalisme, banyaknya perkelahian, pemerkosaan dan sebagian lainnya.

Pemerintah dan masyarakat setempat sangat berharap penuh terhadap pemuda yang memiliki inovasi-inovasi dalam berorganisasi karena mereka akan merasakan secara langsung dampaknya namun pemuda kini memiliki karakter yang selalu ingin diajak, dirangkul dan selalu malu untuk menampilkan potensi dirinya masing-masing padahal pemuda pasti memiliki kemampuan yang lebih dibandingkan para orang dewasa dan lanjut usia. Selain kaderisasi dalam pemuda khususnya dalam karang taruna sangat kurang hal ini sama dengan permasalahan di karang taruna Rw03 Desa Nanjung Kecamatan Margaasih Kabupaten Bandung.

Banyaknya permasalahan di Karang Taruna desa nanjung margaasih diantaranya kuranya dukungan moral dan moril dari pemerintah setempat sehingga akan mempengaruhi program yang akan dilaksanakan oleh karang taruna. Latar pendidikan anggota karang taruna yaitu, SMP 40\%, SMA 50\%, PT 10\%. Fasilitas yang ada dalam karang taruna belum memadai untuk berjalannya suatu program sehingga akan menyulitkan para anggota karang taruna untuk berpartisipasi secara sukarela.

Karang Taruna yang ada di Rw 03 desa Nanjung kecamatan Margaasih memiliki banyak anggota setengah dari anggotanya adalah laki-laki data ini di peroleh dari profil karang taruna. Karang Taruna tersebut memiliki keunggulan-keunggulan dalam program nya sehingga selalu mengadakan acara-acara Peringatan Hari Besar Nasional (PHBN) namun kegiatan tersebut kurang adanya partisipasi dari anggota maupun para pemuda. Partisipasi merupakan keterlibatan atau keikutsertaan seseorang terhadap suatu organisasi atau kegiatan. Dalam partisipasi ada beberapa jenis diantaranya dengan uang, tenaga, pikiran dan keterampilan. Ada pula bentuk partisipasi diantaranya yaitu sukarela, paksaan, ikut-ikutan dll.

Penulis telah merumuskan beberapa masalah yang ada yaitu (1) Bagaimana upaya tokoh pemuda dalam meningkatkan partisipasi karang taruna (2) Bagimana Bentuk partisipasi karang taruna dalam meningkatkan program kerja. Adapun tujuan dari penelitian ini adalah untuk mengetahui upaya tokoh pemuda dalam meningkatkan partisipasi karang taruna dan untuk mengetahui partisipasi karang taruna dalam meningkatkan program kerja.

\section{KAJIAN TEORI}

\section{A. Pengertian Karang Taruna}

Organisasi kepemudaan di masyarakat sangatlah banyak diantaranya adaorganisasi pemuda pancasila, organisasi karang taruna, organisasi remaja masjid. Namun organisasi yang banyak mencuru perhatian adalah organisasi karang taruna karena karang taruna merupakan organisasi yang netral tidak membedakan suku, ras atau agama. Menurut Wenti 
Siti Ningrum (2013: 391) "Karang Taruna adalah suatu organisasi kepemudaan yang ada di Indonesia dan merupakan sebuah wadah tempat pengembangan jiwa sosial pemuda." Dengan teori yang telah dijabarkann dapat kita ketahui bahwa karang taruna adalah sebuah kumpulan bagi para pemuda untuk menuangkan bakat dan sebagai ajang berkreasi, banyak ide-ide yang terlahir dari karang taruna untuk masyarakat karena karang taruna tumbuh berkat kesadaran dan tanggung jawab dari masyarakat dan untuk masyarakat. Telah kita ketahui bersama bahwa kiprah para pemuda dari zaman kemerdekaan sangatlah membantu, pemuda kini dengan segala ide dan kreativitasnya pun sangat membantu dilingkungannya sendiri.

Berdasarkan Undang-Undang Nomor 77 Tahun 2010 tentang Pedoman Dasar Karang Taruna "Karang Taruna merupakan salah satu organisasi sosial kemasyarakatan yang diakui keberadaannya dalam penyelenggaraan kesejahteraan sosial ". Kementrian olahraga dan kepemudaan telah menjabarkan bahwa karang taruna adalah sebuah kegiatan para pemuda untuk melaksanakan usaha kesejahteraan sosial (UKS), selanjutnya karang taruna harus bisa mengembangkan sumbar daya manusia (SDM). Karang taruna tumbuh di masyarakat berdasarkan adanya kesadaran dari para pemuda dan pemudi karena banyaknya permasalahan yang ada di dalam lingkungannya. Karang taruna di kelola oleh pemuda yang digawangi oleh pemerintahan setempat untuk dirinya dan masyarakat.

Karang taruna harus memiliki tanggung jawab atas dirinya dan lingkungannya terhadap masalah-masalah sosial yang ada di masyarakat, tidak hanya tanggung jawab sebagai anggota karang taruna harus memiliki kepribadian yang baik serta berpengetahuan. Salah satu tujuan karang taruna adalah sebagai pelopor di masyarakat yang mampu meningkatkan kualitas organisasi di daerahnya.

Tujuan karang taruna memiliki beberapa tujuan yang mana keseluruhannya untuk masyarakat, kemudian disamping itu tujuan khusus sebuah karang taruna adalah mampu meningkatkan kualitas dirinya di masyarakat.

Fungsi utama karang taruna yaitu untuk meningkatkan kualitas domisilinya agar lebih maju, ada beberapa cara yaitu dengan keexistensian karang taruna itu sendiri dengan berbagai kegiatan yang positif diantaranya dengan mengadakan acara-acara peringatan hari besar nasional, penyelenggaraan peduli terhadap kaum disabilitas, dhuafa, cancer dan lainnya.

\section{B. Konsep Pemimpin dan Kepemimpinan}

1. Pemimpin

Didalam tahapan organisasi selalu adanya pemimpin yang salah satunya adalah bertugas bertanggung jawab atas anggotanya sebagaimana Menurut Hasibuan (2011:157) "pemimpin merupakan seseorang yang memiliki wewenang dan jabatan, dimana keduanya digunakan untuk mengarahkan orang lain atau bawahan dan mampu bertanggung jawab atas pekerjaannya“. Selain itu pemimpin adalah seseorang yang di patuhi bicaranya dan sebagai anggota atau bawahan kita wajib untuk menghormatinya.

Sedangkan menurut Menurut Kartono (2016:18) "pemimpin adalah seorang pribadi 
yang memiliki kecakapan dan kelebihan, khususnya kecakapan dan kelebihan di satu bidang sehingga dia mampu mempengaruhi orang lain untuk bersama-sama melakukan aktivitas-aktivitas tertentu demi pencapaian satu atau beberapa tujuan“. Seorang pemimpin sebaiknya harus memiliki kemampuan yang mumpuni dibidangnya agar dapat menunjang dalam pekerjaanya sebagaimana teori yang telah dipaparkan diatas bahwa memiliki kemampuan yang mumpuni dibidangnya agar mampu mengajarkan para bawahnnya untuk mencapai tujuan dirinya dan perusahaan.

Seorang pemimpin harus bertanggung jawab atas dirinya dan organisasinya, selain itu seorang pemimpin harus mempunyai integritas, wibawa dan optimisme yang tinggi. Selain itu dalam profil kepemimpinan pemuda indonesia menyebutkan bahwa seorang pemimpin harus taqwa, mandiri, profesional, peduli dan memiliki rasa patriotisme.

\section{Kepemimpinan}

Kartono (2016:5-8) berpendapat bahwa "kepemimpinan merupakan salah relasi dan pengaruh antara pemimpin dengan yang dipimpin. Kepemimpinan tersebut muncul dan berkembang sebagai hasil dari interaksi otomatis anatara pemimpin dengan orang-orang yang dipimpinnya". Berdasarkan definisi di atas dapat disimpulkan bahwa kepemimpinan merupakan kemampuan seseorang untuk mempengaruhi dan mengarahkan orang secara efektif dan efisien dalam rangka mencapai tujuan. Kepemimpinan merupakan sifat yang patut dimiliki oleh pemimpin.selain itu pemimpin harus memiliki loyalitas yang tinggi untuk organisasinya dan untuk anggotanya.

Menurut Handoko (2003) pemimpin memiliki 10 ciri utama yaitu diantaranya: "Kecerdasan, Kedewasaan, Sosial dan Hubungan Sosial yang luas, Motivasi diri, dorongan berprestasi, Sikap-sikap hubungan manusiawi, memiliki Pengaruh Yang Kuat, Memiliki Pola Hubungan Yang Baik, Memiliki Sifat-Sifat Tertentu, memiliki Kedudukan atau Jabatan, Mampu Berinteraksi dan Mampu Memberdayakan“. Seorang pemipin akan dipertanggung jawabkan nanti di hadapan sang pencipta atas segala yang dilakukannya selama menjadi seorang pemipin. 10 ciri utama diatas merupakan acuan bagi seorang pemimpin dan yang menjadi point utama adalah seorang pemimpin harus memiliki kecerdasan untuk mampu membimbing dan mengarahkan, memiliki pengaruh yang kuat dan mempunyai hubungan sosial yang luas dan baik.

Ada beberapa gaya dalam kepemimpinan. Menurut Bambang Syamsul Arifin (2015) ada tiga macam gaya kepemimpinan yaitu gaya kepemimpinan otoriter, gaya kepemimpinan demokratis dan gaya kepemimpinan laizes faire berikut penjelasannya :

\section{1) Gaya Kepemimpinan Otoriter}

Gaya kepemimpinan otoriter sangat mengandalkan kekuasaan bagi seorang pemimpin dimana pemimpin memberikan tugas kepada bawahannya sehingga bawahan harus senantiasa patuh kepada segala tugas dan intruksi pemimpin. Gaya kepemimpinan otoriter biasa di gunakan dalam militer sebab gaya kepemimpinannya sifatnya diktator dan senioritas. Dan segala keputusan ada dalam kebijakan pemimpin. 


\section{2) Gaya Kepemimpinan Demokratis}

Gaya kepemimpinan demokratis menggunakan kerjasama dalam setiap pekerjaannya kemudian pemimpin dijadikan sebagai leader. Gaya kepemimpinan ini menggunakan pengambilan keputusan secara kooperatif. Pemimpin cenderung mendengarkan keluhan bawahan dan dicari solusinya namun kepemimpinan ini kurang adanya ketegasan dalam keputusan.

\section{3) Gaya Kepemimpinan Bebas (laissez-faire)}

Gaya kepemimpinan laizes faire memberikan keleluasaan, keterbukaan dan kekuasaan penuh terhadap bawahan. Posisi pemimpin hanya sebagai fasilitator untuk menyediakan hal yang dibutuhkan oleh bawahannya.

Menurut Sudjana (2010:27) "Ada beberapa teori dalam kepemimpinan diantaranya adalah teori sifat, teori lingkungan, teori perilaku, teori humanistik dan teori kontigensi." Teori sifat adalah sifat-sifat dan ciri-ciri yang dimiliki seorang pemimpin, menurut odway tead sifat pemimpin itu kuat jasmani, memiliki loyalitas tinggi mempunyai tujuan dan arah yang pasti, mampu berkomunikasi dengan baik, menarik, pintar, ramah, sopan, berkpribadian yang baik, mampu mengambil keputusan dan dapat mengembangkan kecakapan teknis.

Teori lingkungan itu terbentuk berdasarkan waktu, tempat dan kondisi. Teori lain yang sejalan dengan teori lingkungan menyebutkan bahwa pemimpin pemimpin itu di bentuk bukan dilahirkan. Teori ini beranggapan bahwa seorang pemimpin bukan karena adanya garis keturunan tapi berdasarkan lingkungan sosial dengan berbagai permasalahan yang menuntunya agar menjadi seorang pemimpin.

Teori perilaku lebih menjelaskan tentang perbuatan pemimpin yang mengacu kepada dua gaya kepemimpinan yaitu konsiderasi atau perilaku pemimpin yang memperhatikan kepentingan bawahan dengan memberikan perlakuan bawahan, selalu mementingkan kesejahteraan bawahan, mau berkonsultasi serta hal lainnya yang merupakan kepentingan bawahan dan insiasi atau pemimpin yang lebih mementingkan tujuan organisasi dengan cara memberikan tugas, memberikan kritik ketika salah, menekankan target dan hal lainnya untuk dapat mencapai tujuan organisasi.

Teori humanistik adalah teori yang memanusiakan manusia dalam artian mengetahui batasan-batasan yang dimiliki oleh seorang manusia. Anggapan dasar bahwa manusia adalah mahluk yang harus dimotivasi sedangkan organisasi adalah bentuk yang harus diawasi, dengan begitu ketika seorang pemimpin akan menyusun sebuah organisasi alahkah baiknya memberikan keleluasan kepada bawahannya namun dalam porsinya agar terpenuhi dan tercapai tujuan organisasi.

Teori kontigensi mengusung tiga unsur yang mempengaruhi gaya kepemimpinan yaitu kewibawaan posisi kepemimpinan, hubungan pemimpin dan bawahan, dan bentuk tugas.

\section{Partisipasi}

Partisipasi adalah kesukarelaan seseorang dalam mengikuti kegiatan yang diadakan 
oleh organisasi atau pemerintah untuk mencapai tujuan tertentu. Menurut Isbandi (2007: 10 ) "partisipasi adalah keikutsertaan masyarakat dalam proses pengidentifikasian masalah dan potensi yang ada di masyarakat, pemilihan dan pengambilan keputusan tentang lternatif solusi untuk menangani masalah, pelaksanaan upaya mengatsi masalah, dan keterlibatan masyarakat dalam proses mengevaluasi perubahan yang terjadi“. Sedangkan menurut kariangga (2011: 221) "Partisipasi masyarakat merupakan proses dimana seluruh pihak masyarakat dapat membentuk dan terlibat dalam seluruh proses pembangunan“. Dapat disimpulkan bahwa suatu partisipasi merupakan keterlibatan seseorang dalam suatu kegiatan untuk mencapai tujuan yang sama.

Pada prinsipnya partisipasi harus bersifat secara aktif bukan pasif agar kegiatan berjalan sesuai dengan yang direncanakan dan setiap seseorang yang berpartisipasi dalam prinsipnya harus mengetahui dari mulai proses identifikasi, perencanaan, pelaksanaan dan evaluasi agar dapat mengikuti dan memberi saran dan masukan terhadap setiap kegiatan yang akan dilakukan. "Prinsip partisipasi adaah masyarakat berperan secara aktif dalam proses atau alur tahapan program dan pengawasannya, mulai tahap dari sosialisasi, perencanaan, pelaksanaan, dan pelestarian dengan bentuk sumbangan pikiran, tenaga, ataupun materil“ (PTO PNPM PPK,2007)

Partisipasi adalah keikutsertaanya seseorang dalam kegiatan organisasinya untuk mencapai tujuan yang mereka capai. Partisipasi merupakan keterlibatan seseorang secara sadar ke dalam suatu kegiatan atau situasi tertentu. Dapat disimpulakan bahwa seseorang mau berpartisipasi ketika mereka memiliki tujuan yang samadan mereka peduli dan membutuhkan terhadap kegiatan atau situasi tertentu. Partisipasi masyarakat menurut Isbandi (2013:27) adalah "keikutsertaan masyarakat dalam proses pengidentifikasian masalah dan potensi yang ada di masyarakat, pemilihan dan pengambilan keputusan tentang alternatif solusi untuk menangani masalah, pelaksanaan upaya mengatasi masalah, dan keterlibatan masyarakat dalam proses mengevaluasi perubahan yang terjadi“.

Partisipasi adalah keterlibatan seseorang dalam suatu kegiatan di masyarakat untuk bisa ikut dalam pengambilan keputusan dengan proses musyawarah, dan hal tersebut merupakan kepentingan bagi dirinya dan masyarakat

Menurut Effendi (siti Irene: 2011: 58) partisipasi dibentuk menjadi dua bagian yaitu horizontal dan vertikal. Partisipasi horizontal adalah posisi masyarakat yang berpartisipasi sama dengan anggota lainnya, memiliki hak dan kewajiban yang sama pula. Sedangkan partisipasi vertikal telah ada posisi tertentu bagi masyarakat berpartisipasi hubungannya antara bawahan dan atasan. Namun setelah dikaji lebih luas Partisipasi memiliki beberapa bentuk yaitu partisipasi menggunakan uang untuk memperlancar dan memenuhi setiap kebutuhan, partisipasi menggunakan pikiran untuk pengambilan keputusaan, partisipasi menggukan tenaga untuk pelaksanaan yang dapat menunjang keberhasilan acara, partisipasi menggunakan keterampilan memberikan keterampilan yang dimiliki untuk keberhasilan acara yaitu dengan dan partisipasi natura atau harta benda yaitu dengan memberikan bantuan dalam bentuk benda. 
Partisipasi secara lengkap bukan hanya keikutsertaan seseorang dalam pelaksanaan kegiatan namun keikutsertaannya dimulai dari identifikasi, pengambilan keputusan, pelaksanaan, dan evaluasi.

\section{METODE PENELITIAN}

Pendekatan yang digunakan adalah pendekatan kualitatif melalui pendekatan ini diharapkan peneliti dapat menghasilkan data yang bersifat deskriptif guna mengungkap sebab dan proses terjadinya di lapangan.

"Metode yang digunakan dalam metode kualitatif adalah wawancara dan observasi" (Sugiyono : 2014). Wawancara dilakukan oleh peneliti melalui tatap muka dengan narasumber, pelaksanaan wawancara terbagi dalam tiga tahap yaitu persiapan, pelaksanaan dan tutup. Observasi adalah proses pengamatan suatu peristiwa dengan cara mencatat data atau dengan mendapatkan informasi secara sistematis.

Instrumen penelitian atau alat pengumpul data adalah kamera, handphone,pulpen dan buku. Alat tersebut di gunakan ketika observasi, wawancara dan dokumentasi.

Penelitian ini dilakukan di Rw 03 Desa Nanjung Kecamatan Margaasih Kabupaten Bandung dengan waktu januari-maret

\section{HASIL DAN PEMBAHASAN}

\section{A. Hasil}

Hasil penelitian dan pembahasan mengenai partisipasi karang taruna di Rw 03 desa nanjung kecamatan margaasih yaitu;

A. HASIL

1. Partisipasi anggota karang taruna di desa nanjung rw 03 dibidang kegiatan dalam mengadakan acara Peringatan hari besar nasional telah mendapatkan respon yang baik dari masyarakat . program PHBN ini telah memiliki beberapa agenda yang akan di laksanakan yaitu peringatan hari besar nasional itu sendiri antara lain 17 agustusan, sumpah pemuda, maulid nabi, dan isra miraj

2. Partisipasi karang taruna di bangun oleh tokoh pemuda yang menekankan para anggota karang taruna melalui sebuah kumpulan yang didalamnya terdapat nasihat dan pengarahan dalam proses dan pelaksanaan kegiatan acara PHBN

3. Bentuk partisipasi yang digunakan oleh para anggota karang taruna 75 persen oleh partisipasi uang dan tenaga. Partisipasi menggunakan uang untuk modal utama agar sarana dan prasarana terpenuhi dan partisipasi tenaga dari mulai persiapan dan pelaksanaan acara sedangkan dalam evaluasi hanya setengah dari keanggotaan.

4. Banyak para pemuda yang bukan anggota karang taruna yang ikut berpartisipasi dalam pelaksanaan kegiatan acara PHBN

\section{B. Pembahasan}

Seorang tokoh dalam masyarakat merupakan sosok yang di anggap memiliki pengetahuan tinggi, wibawa tinggi, dan kharisma yang tinggi di banding dengan masyarakat lainnya. Ada beberapa tokoh dalam masyarakat diantaranya tokoh 
masyarakat, tokoh agama, tokoh perempuan dan tokoh pemuda. Disini tokoh pemuda memiliki peranan aktif dalam membentuk sikap dan karakter pemuda yang ada di masyarakat. Peranan tokoh pemuda di masyarakat yaitu memimpin, membibing, memandu dan menolong pemuda yang ada di masyarakat khususnya karang taruna. Hal tersebut menjadikan bahwa tokoh pemuda dalam tugas dan fungsinya adalah sebagai seseorang yang dipercaya mampu memberikan masukan, contoh, nasihat, dan pengabdiannya bagi pemuda di masyarakat khususnya karang taruna.

Begitu pula di Desa Nanjung kecamatan Margaasih ini seorang tokoh pemuda memiliki peranan penting dalam organiasi karang taruna. Tokoh pemuda yang berada di desa Nanjung Rw 03 kecamatan Margaasih selalu memberikan gambaran-gambaran, masukan dan saran terhadap program yang sedang di laksanakan dan program yang akan dilaksanakan kemudian beliau turun langsung dalam mengajak para pemuda dan anggota karang taruna untuk mengikuti setiap kegiatan-kegiatan kepemudaan khususnya program karang taruna dengan cara membimbingnya, menasihati dan memberikan pandangan yang bermanfaat bagi para pemuda dan anggota karang taruna. Namun tokoh pemuda yang berada di desa Nanjung Rw 03 kecamatan Margaasih ini kurang memiliki ketegasan dalam mengatur para pemuda dan anggota karang taruna hal ini mungkin tokoh pemuda lebih menerima yang mau bekerja saja. Dalam kepemimpinananya tokoh pemuda di desa Nanjung ini menganut teori sifat yang mana beliau seorang pemimpin yang memiliki loyalitas tinggi, mempunyai tujuan dan arah yang pasti, berkepribadian yang baik serta mampu mengambil keputusan yang bijak. Sedangkan dalam gaya kepemimpinan tokoh pemuda disini lebih mengarah pada gaya demokratis.

Partisipasi merupakan sesuatu yang selalu terjadi dalam sebuah kegiatan dimana satu dengan yang lainnya saling mendukung dengan memberikan sumbangan fikiran, tenaga dan materil. Partisipasi berasal dari bahasa inggris yakni to participate yaitu ikut serta atau mengambil bagian. Partisipasi berasal dari pribadi masing-masing yang menenukan, namun kita sebagai pemuda sepatutnya kita berperan aktif di dalam atau luar masyarakat karena hal ini menjadi salah satu tugas pemuda untuk selalu produktif. Hal tersebut telah melandasi bahwa pemuda yang ada di masyarakat untuk turun serta berpartisipasi agar mengikuti kegiatan dalam perencanaan, pelaksanaan hingga evaluasi. Jika ditinjau dari segi motivasi menurut Siti Irene (2011: 57) partisipasi terjadi karena yaitu diantaranya: Takut atau keterpaksaaan, ikut-ikutan, kesadaran. Menurut Keith (Ibrahim: 2006) "Mengkalsifikasikan bentuk partisipasi diantaranya: partisipasi uang, partisipasi harta, partisipasi tenaga dan partisipasi keterampilan “. Dalam partisipasi karang taruna dalam acara PHBN ini 75 persen menggunakan partisipasi tenaga yang digunakan untuk menlaksanan acara yang memerlukan tenaga lebih karena banyak yang harus dipersiapkan dalam melaksanakan sebuah acara PHBN dan partisipasi uang yang digunakan untuk memenuhi dan memperlancar kegiatan acara PHBN .

Karang Taruna di Rw 03 Desa Nanjung kecamatan Margaasih memiliki 25 orang anggota yang aktif, namun ketika akan mengadakan suatu kegiatan atau acara banyak pemuda dan anggota karang taruna lainnya yang ikut berpartisipasi, bentuk partisipasi yang mereka berikan yaitu partisipasi menggunakan uang, dan partisipasi menggunakan tenaga. Keterlibatan seluruh anggota karang taruna dalam berbagai 
kegiatan yang berhubungan dengan pemberdayaan masyarakat diharapkan akan mendorong dan menumbuhkembangkan kekuatan sosial dalam konteks pemberdayaan masyarakat, terutama dalam menghadapi tantangan global, dimana pemuda memgang peranan penting dalam menentukan kehidupan masyarakat di masa yang akan datang. Potensi ekologi, hanya bisa dikembangkan bilamana terdapat inisiator dalam pembangunan masyarakat sekitar. Karena pada dasarnya seringkali permasalahan yang dihadapi dalam pemberdayaan masyarakat adalah kendala menghadirkan pemuda dalam pembangunan masyarakatnya sendiri. Bilamana pemuda telah dapat berperan, maka hal tersebut akan menjadi modal sosial dalam pembangunan masyarakat ke depan (Ardiwinata dan Mulyono, 2018).

\section{PENUTUP}

\section{Kesimpulan}

Sesuai dengan hasil penelitian dan pembahasan yang dilakukan mengenai partisipasi karang taruna di Rw 03 desa nanjung kecamatan margaasih kabupaten bandung, maka dapat disimpulkan ;

1. Partisipasi anggota karang taruna di desa nanjung rw 03 dibidang kegiatan dalam mengadakan acara Peringatan hari besar nasional telah mendapatkan respon yang baik dari masyarakat . program PHBN ini telah memiliki beberapa agenda yang akan di laksanakan yaitu peringatan hari besar nasional itu sendiri antara lain 17 agustusan, sumpah pemuda, maulid nabi, dan isra miraj

2. Partisipasi karang taruna di bangun oleh tokoh pemuda yang menekankan para anggota karang taruna melalui sebuah kumpulan yang didalamnya terdapat nasihat dan pengarahan dalam proses dan pelaksanaan kegiatan acara PHBN

3. Bentuk partisipasi yang digunakan oleh para anggota karang taruna 75 persen oleh partisipasi uang dan tenaga. Mereka mengeluarkan uang untuk modal utama agar sarana dan prasarana terpenuhi dan partisipasi tenaga dari mulai persiapan dan pelaksanaan acara sedangkan dalam evaluasi hanya setengah dari keanggotaan.

4. Banyak para pemuda yang bukan anggota karang taruna yang ikut berpartisipasi dalam pelaksanaan kegiatan acara PHBN

\section{Saran}

Setelah peneliti melakukan penelitian terhadap partisipasi karang taruna di Rw 03 Desa Nanjung kecamatan Margaasih Kabupaten Bandung, Peneliti memberikan beberapa saran diantaranya adalah;

1. Seorang tokoh pemuda hendaknya dapat memberikan motivasi yang jauh lebih baik agar kemampuan karang taruna semakin maju tidak dibidang itu itu saja, misalnya seorang tokoh pemuda memberikan gambaran tentang lingkungannya agar anggota karang taruna lebih peduli terhadap lingkungannya

2. Sering mengadakan kumpulan yang bermakna walaupun tidak ada acara PHBN agar bisa meningkatkan hubungan erat antara anggota karang taruna lainnya dan agar lebih kompak bagi karang taruna itu sendiri.

3. Seorang tokoh pemuda harus lebih bisa merangkul baik anggota karang taruna maupun para pemuda untuk terlibat secara aktif dalam acara PHBN

4. Harus adanya kaderisasi dari kepemimpinan sebelumnya agar anggota yang baru dapat mengikuti jejak sebelumnya 
5. Harus mengadakan perekrutan anggota karang taruna baru untuk lebih meningkatkan kuota anggota karang taruna 


\section{DAFTAR PUSTAKA}

Ardiwinata , J. S. dan Mulyono, D. 2018. Community Education in the development of The Community. Jurnal Empowerment, Vol. 7 (1), hal. 25-35

Arifin, B.S. 2015. Dinamika Kelompok. Bandung: Pustaka setia

Jurnal: Mawaddah, EF. 2016. Partisipasi Pemuda Dalam Program Karang Taruna Di Bidang Kesenian Di Desa Tanjungharjo Kecamatan Nanggulang Kabupaten Kulon Progo.

Isbandi, R.A. 2007. Perencanaan Partisipatoris Berbasis Aset Komunitas; Dari Pemikiran Rakyat Menuju Penerapan. Depok; FISIP UI Press

Kartono, K. 2016. Pemimpin dan kepemimpinan. Makasar; Rajawali pers

Kariangga, H. 2011. Partisipasi Masyarakat Dalam Pengelolaan Keuangan Daerah (Perspektif Hukum Dan Demokrasi ). Bandung: PT. Alumni

Ningrum, S.I. 2011. Desentralisasi dan partisipasi masyarakat dalam pendidikan. Yokyakarta : pustaka pelajar

Sugiyono. 2014. Metode Penelitian Kualitatif, Kuantitatif dan R\&D. Bandung : Alfabeta

Sudjana. 2010. Manajemen Program Pendidikan untuk nonformal. Bandung : Falah Production

Skripsi: Suhendar. 2012. Partisipasi masyarakat dalam program nasional pemberdayaan masyarakat (PNPM) di Desa Karyasari Kecamatan Sukaresmi Kabupaten Pandeglang

Wibowo, etc. 2010. Modul Pelatihan Kepemimpinan Pemuda Indonesia: Deputi pengembangan kepemiminan pemuda dan olahraga 